\title{
The Effect of Radiofrequency Ablation on Stem Cells and Systemic Inflammation in Patients with Supraventricular Tachycardia
}

\section{Supraventriküler Taşikardili Hastalarda Radyofrekans Ablasyonun Kök Hücre ve Sistemik Inflamasyona Etkisi}

Ahmet Lutfu Sertdemir ${ }^{1}$

Halil Ibrahim Erdogan ${ }^{1}$,

Bahadir Feyzioglu²,

Mehmet Tokac ${ }^{3}$,

Ilknur $\mathrm{Can}^{4}$

${ }^{1}$ Department of Cardiology, Necmettin Erbakan University, Konya, Turkey

${ }^{2}$ Department of Medical Microbiology,

Necmettin Erbakan University, Konya, Turkey

${ }^{3}$ Department of Cardiology, Katip Celebi

University, Izmir, Turkey

${ }^{4}$ Department of Cardiology, University of

Minnesota, Minneapolis, USA

Geliş Tarihi/Received: 28 September 2018 Kabul Tarihi/Accepted: 30 October 2018

Address correspondence to: Ahmet Lutfu Sertdemir, Department of Cardiology, Necmettin Erbakan University, Konya, Turkey

e-mail:dralsertdemir@gmail.com

ORCID

Ahmet Lutfu Sertdemir

https://orcid.org/0000-0002-4656-5547

\begin{abstract}
Öz
Amaç: Kemik iliğinde bulunan kök hücreler, doku onarımını artırmak için miyokardiyal hasar sonrası dolaşıma salınmaktadır. Başta atriyal fibrilasyon olmak üzere; kardiyak aritmilerin radyofrekans ile ablasyonu sonrası dolaşımda bulunan kök hücrelerin inflamatuar aracılar vasıtasıyla salınımının tetiklendiği gösterilmiştir. Bizim çalışmamızda, yavaş yol veya aksesuar yol gibi geniş olmayan ablasyon işlemlerinden sonra dolaşımdaki kök hücre sayısının artıp artmadığı araştırıımıştır.

Hastalar ve Yöntem: 26 hastaya [yaş 54 (18-74)] radyofrekans ablasyon işlemi uygulandı. Bu hastalardan 18 'ine atriyoventriküler nodal reentran taşikardi nedeniyle yavaş yol ablasyonu; 8'ine ise atriyoventriküler reentran taşikardi nedeniyle aksesuar yol ablasyonu yapıldı. Hastalarda periferik dolaşımdan alınan kan örneklerinde işlem öncesi ve işlem sonrası 7. ve 30. günlerde CD34+ hücre sayıları ve çeşitli serolojik belirteçlerin [Troponin-I (Tn-I), interlökin-6 (IL-6), Stromal deriveted faktör 1-a (SDF 1- $\alpha$ ) ve C-reaktif protein (CRP)] düzeyleri incelendi.

Bulgular: CD34+ hücrelerin, işlem sonrası 7. günde bazal ölçüme gore anlamlı artış gösterdiği [33 (15$133)$ vs. 22,5 (5-79) hücre/mikrolitre sırasıyla, $P<0.001$ ] ve 30 . günde bazal seviyelere indiği gözlendi Ablasyon sonrası Tn-I, CRP, IL-6 ve SDF1- $\alpha$ düzeylerinde istatiksel anlamlı artış izlenmedi. İşlem sırasında uygulanan enerji miktarı (watt) ile işlem sonrası 30. günde artan CD34+ hücreleri arasında doğru orantı izlendi ( $r: 0.460 ; p=0.018$ )

Sonuç: Çalışmamızda periferik kanda bulunan kök hücrelerin atriyal fibrilasyon ablasyonundan daha az enerji uygulanan yavaş yol veya aksesuar yol ablasyonundan sonrası 7. günde anlamlı şekilde arttığı ve izlemde 30. günde bazal seviyelerine döndüğü gösterilmiştir. Ayrıca, dolaşımda bulunan kök hücrelerdeki artışın işlem sırasında uygulanan eneji miktarı ile doğru orantılı olduğu da bulunmuştur.
\end{abstract}

Anahtar Kelimeler: Radyofrekans ablasyon, kök hücre, subraventriküler taşikardi

\section{Abstract}

Aim: Circulating stem cells (CSCs) are released from bone marrow in to the circulation after myocardia injury to improve tissue repair. Radiofrequency ablation (RFA) of cardiac arrhythmias, particularly for atria fibrillation, has been shown to trigger the release of CSCs through inflammatory mediators. We aimed to investigate whether CSCs are increased in the circulation following non-extensive ablation procedures such as slow pathway or accessory pathway ablations.

Patients and Methods: Twenty-six patients [13 females, 54 (18-74) years old] who underwent slow pathway ablation for atrioventricular nodal reentrant tachycardia $(n=18)$ and accessory pathway ablation for atrioventricular reentrant tachycardia $(n=8)$ were included. Peripheral blood CD34+ cell count and multiple serologic markers [troponin I (Tn-I), C-reactive protein (CRP), interleukin-6 (IL-6), stromal cell derived factor (SDF) 1 alpha] were evaluated before the ablation procedure and 7 and 30 days after the procedure.

Results: The CD34+ cell count was significantly increased on the 7 th day after the procedure when compared to baseline [33 (15-133) vs. $22,5(5-79)$ cells per microliter respectively, $P<0.001]$. The CD34+ cell count was similar to baseline on the 30 th day following the procedure. Levels of Tn-I, CRP, IL-6 and SDF1- $\alpha$ did not change significantly following ablation. The amount of energy applied during RFA (watts) was significantly correlated with the 30th day CD34+ cell count $(r: 0.460 ; p=0.018)$.

Conclusions: Peripheral blood CSCs are increased after slow pathway or accessory pathway ablations which are less extensive ablations compared to atrial fibrillation ablation. The levels return to baseline by the 30th day following the procedure. The increase in CSCs was positively correlated with the amount of energy delivered during the procedure.

Key words: Radiofrequency ablation, stem cells, supraventricular tachycardia

\section{INTRODUCTION}

Circulating stem cell (CSC) count is known to increase in soft tissue injuries in the setting of myocardial infarction, severe burns and coronary artery bypass grafting $(1,2)$. Stem cells contribute to repair following tissue trauma and inflammation $(3,4)$. Necrosis occurs in the myocardium during radiofrequency ablation (RFA). Consequently, release of inflammatory cytokines and stem cells is triggered. Previous studies have shown significant increase
Cite this article as: Sertdemir AL, Erdogan HI, .Feyzioglu B, Tokac M, Can I. The Effect of Radiofrequency Ablation on Stem Cells and Systemic Inflammation in Patients with Supraventricular Tachycardia. Selcuk Med J 2019;35(4): 225-229
Disclosure: None of the authors has a financial interest in any of the products, devices, or drugs mentioned in this article. The research was not sponsored by an outside organization. All authors have agreed to allow full access to the primary data and to allow the journal to review the data if requested. 
in inflammatory cytokine levels and stem cell count during long- lasting and extensive ablation in patients undergoing ablation for atrial fibrillation $(A F)(5,6)$.

Atrioventricular reentrant tachycardia (AVRT) and atrioventricular nodal reentrant tachycardia (AVNRT) are common supraventricular arrhythmias that present mostly in early adulthood (7). Catheter ablation is recommended as first- line treatment strategy in patients with recurrent symptomatic episodes of both arrhythmias and is preferred frequently since the procedure is curative $(8,9)$. RF energy is applied to a relatively restricted area during AVRT and AVNRT ablations; therefore less tissue injury is expected to occur in comparison to AF ablations. The impact of tissue injury following catheter ablation for AVRT and AVNRT on stem cell mobilization from bone marrow and levels of related cytokines are unclear.

In this study, we aimed to investigate the effect of RFA for AVRT and AVNRT on stem cell mobilization from bone marrow and levels of related inflammatory cytokines. For this purpose, levels of C-reactive protein (CRP), interleukin 6 (IL-6), Troponin-I (TnI), stromal cell derived factor 1 alpha (SDF-1 $1 \alpha$ ) and CD34+ cell count were measured.

\section{PATIENTS AND METHODS}

\section{Study population}

The study population included 26 patients (1880 years old) who were scheduled for RFA for supraventricular tachycardia (AVNRT or AVRT). The duration of follow-up was one month after RFA. Patients with a prior history of hematologic, inflammatory or infectious diseases were not included. In addition, patients who previously received medications that are known to affect the bone marrow were excluded.

Peripheral venous blood samples were obtained from patients before the procedure and on days 7 and 30 post- procedure. Blood samples were analyzed for CRP, IL- 6, Tn- I, SDF-1a levels and CD34+ stem cell count.

This study was approved by the local ethical committee (number:2014/86) and informed consent was obtained from all participants.

\section{Radiofrequency Catheter Ablation}

Two quadripolar and one decapolar catheters were inserted to perform a standard electrophysiological study. The catheters were advanced into the heart and positioned respectively in the right ventricular apex, on the His bundle and in the coronary sinus. Induction of AVNRT or AVRT was performed at least two times before moving forward to ablation. RF catheter ablation was performed using a 4-mm, solidtip, ablation catheter (Medtronic MarinrMulticurve steerable, MN, USA) in a temperature-controlled mode (maximum temperature $60^{\circ} \mathrm{C}$, maximum duration 60 $\mathrm{s}$, maximum $50 \mathrm{~W}$ ) with the use of a AtakrRF generator (Medtronic, MN, USA). Left-sided pathways were approached after obtaining trans-septal access to left atrium. Ablation of the slow pathway or accessory pathway was guided by a combination of intracardiac electrograms and anatomical landmarks. Fluoroscopy was used throughout each application.

\section{ELISA}

Serum samples were analyzed for human CRP, IL-6, Tn-I and SDF-1a protein levels by using enzyme-linked immunoassays (ELISA). Frozen serum samples were thawed rapidly to room temperature and assayed for the presence of human CRP (Shanghai Sunred Biological Tech. China), IL-6 (Shanghai Sunred Biological Tech. China), Tn-I (Shanghai Sunred Biological Tech. China) and SDF-1a proteins(Shanghai Sunred Biological Tech. China) by using ELISA kits in accordance with the manufacturer's instructions. Serial dilutions of human CRP, IL-6, Tn-I and SDF-1a proteins were used to generate a standard curve. The intensity of the color in each well was measured on a microplate reader. Serum levels of human CRP, IL-6, Tn-I and SDF1a proteins were estimated by extrapolation from a log:log linear regression curve determined from the serially diluted human CRP, IL-6, Tn-I and SDF-1a proteins.

\section{Flow Cytometry}

CD34+ cell counts were performed by flow cytometry in peripheral venous blood samples. Blood samples were taken into the citrated tubes. Peripheral blood mononuclear cells (PBMCs) were isolated from these samples by centrifugation. Cell suspensions were labeled with CD34FITC (Becton-Dickinson, Heidelberg,Germany). Cells labeled with CD34 were analyzed by flow cytometry (Becton-Dickinson, Heidelberg,Germany) in which75000 events were counted. The absolute number of cells expressing CD34 per 75000 events in the lymphocyte gate was calculated.

\section{Statistical analysis}

Normally distributed continuous parameters are presented as mean \pm standard deviation and skewed continuous parameters are expressed as median (minimum- maximum). Categorical data are presented as frequencies and percentages. Comparisons between skewed baseline characteristics in 2 groups 
Table 1. Baseline characteristics of the study population.

\begin{tabular}{ll}
\hline $\mathbf{N}=\mathbf{2 6}$ & Median; min; max \\
\hline Age (years) & $54(18-74)$ \\
Height (cm) & $165(155-180)$ \\
Weight (kg) & $82(45-95)$ \\
Ejection fraction (EF,\%) & $60(50-65)$ \\
Duration of RF energy application (sec) & $118(25-720)$ \\
Total energy applied (joule) & $4350(594-35800)$ \\
Mean power (joule/sn) & $45(32-67)$ \\
Mean temperature (oC) & $54(27-65)$ \\
Basic cycle length (msec) & $312(263-390)$ \\
\hline
\end{tabular}

were performed using Mann- Whitney $U$ test. For repeated measurements, Friedman's two- way analysis of variance was applied. Categorical data was compared using chi- square test and exact test (Monte Carlo). Spearman correlation analysis was done to investigate relationship between procedural characteristics (duration of RF energy application, amount of RF energy and power applied) and increase in stem cell count (absolute values and percentage increase). Statistical analyses are performed using SPSS statistical software (IBM SPSS Statistics for Windows, Version 20.0. Armonk, NY: IBM Corp.) A two-tailed $p<0.05$ is considered statistically significant.

\section{RESULTS}

\section{Patients and procedural characteristics}

Twenty-six ( $50 \%$ male) were included in the study. Median age was 54 (18-74) years old. None of the patients had a prior diagnosis of coronary artery disease. Number of patients who were diagnosed with diabetes and hypertension were 4 (15.4\%) and
$10(38.5 \%)$, respectively. Mean ejection fraction was found to be $60 \%$ (Table 1). RFA was performed in 18 patients for AVNRT and in 8 patients for AVRT. Mean duration of RF energy application was 118 seconds in the study population. Mean temperature, applied energy and power were $54^{\circ} \mathrm{C}, 4.350$ joules and 45 joule/sec, respectively (Table 1 ).

Circulating CD34+ stem cells and systemic inflammatory markers

CD34+ stem cell count measurements at three different times are shown in Table 2. CD34+ stem cell count was significantly higher on the 7th day following the procedure when compared to pre-ablation values (35.00 [18-133] vs. 22.50 [5-74] cells per microliter respectively, $p<0.001)$. No statistically significant difference was detected between CD34+ cell counts on the 30thday following the procedure and preablation values (24.00 [7-94] vs. 22.50 [5-74] cells per microliter respectively, $p>0.05$ ).

CRP levels were found to be higher on the 7thday following the procedure compared to baseline;

Table 2. Laboratory parameters of the study population (Mean \pm standard deviation and median; min; max values).

\begin{tabular}{|c|c|c|c|}
\hline & Preprocedural & Postprocedural 7th day & Postprocedural 30th day \\
\hline \multirow[t]{3}{*}{ CD34+ } & $26,62 \pm 17,36$ & $41,57 \pm 25,40$ & $30,58 \pm 20,12$ \\
\hline & 22,$50 ; 5 ; 74$ & $35 ; 18 ; 133$ & $24 ; 4,7 ; 94$ \\
\hline & & $P<0,001^{*}$ & NS \\
\hline \multirow[t]{3}{*}{ Tn-I } & $0,01 \pm 0,113$ & $0,07 \pm 0,22$ & $0,01 \pm 0,005$ \\
\hline & 0,$01 ; 0,01 ; 0,06$ & 0,$01 ; 0,01 ; 1,12$ & 0,$01 ; 0,01 ; 0,03$ \\
\hline & & $P=0,332$ & NS \\
\hline \multirow[t]{3}{*}{ CRP } & $2,94 \pm 1,94$ & $5,43 \pm 5,81$ & $2,40 \pm 1,41$ \\
\hline & $2 ; 0,66 ; 8,90$ & $2 ; 2 ; 22$ & $2 ; 2 ; 7,8$ \\
\hline & & $P=0,066$ & NS \\
\hline \multirow[t]{3}{*}{ IL-6 } & $4,73 \pm 10,15$ & $12,61 \pm 43,01$ & $2,23 \pm 8,90$ \\
\hline & $0 ; 0 ; 43$ & $0 ; 0 ; 45$ & $0 ; 0 ; 45$ \\
\hline & & $P=0,17$ & NS \\
\hline \multirow[t]{3}{*}{ SDF-1a } & $39,60 \pm 26,62$ & $39,66 \pm 28,88$ & $42,16 \pm 29,69$ \\
\hline & 32,$9 ; 7,3 ; 84,4$ & 23,$3 ; 6,4 ; 85,2$ & 32,$7 ; 6,1 ; 86,2$ \\
\hline & & $P=0,7$ & NS \\
\hline
\end{tabular}

VCRP: C- reactive protein, IL-6: interleukin-6, NS: non- significant, SDF-1a: stromal- derived factor-1a, Tn-I: Troponin-I

* denotes statistically significant changes in parameters compared to baseline values. 
Table 3. Relationship between the increase in stem cell count and total energy applied and duration of energy application.

\begin{tabular}{lllll}
\hline Spearman'sRho & & Duration (sec) & Total energy applied (j) & Watt(j/sn) \\
\hline Preablation CD34+ & Rho & 0,084 & 0,162 & 0,121 \\
stem cell count & p & 0,685 & 0,431 & 0,556 \\
Postprocedural 7th day & Rho & 0,090 & 0,132 & 0,017 \\
CD34+ stem cell count & p & 0,664 & 0,520 & 0,934 \\
Postprocedural 30th & Rho & 0,262 & 0,364 & 0,460 \\
day CD34+ stem cell & p & 0,196 & 0,068 & $0,018^{*}$
\end{tabular}

count

* denotes statistically significant changes in parameters compared to baseline values.

however this difference did not reach statistical significance $(5,43 \pm 5,81$ vs. $2,94 \pm 1,94, p=0.066)$. CRP levels on the 30thday following the procedure also did not differ with baseline values. Similar to CRP, IL- 6 levels were found to be higher on the 7thday following the procedure when compared to baseline, however it did not reach statistical significance, too $(12,61 \pm 43,01$ vs. $4,73 \pm 10,15, p=0.17)$. IL-6 levels on the 30thday following the procedure were similar to pre-procedural levels. There was no statistically significant difference between baseline and post-procedural Tn- I and SDF1a levels (Table 2).

There was a statistically significant positive correlation between CSC count on the 30thday following the procedure and the radiofrequency power applied during the ablation ( $r: 0.460 ; p=0.018)$. There was no significant correlation between percentage increase in CSC count and applied energy or duration of RF energy application (Table 3).

\section{DISCUSSION}

Circulating stem cell (CSC) count has been shown to increase following soft tissue injury, such as myocardial infarction, severe burns and bypass grafting $(1,2)$. Similar increase in CSC count has also been demonstrated in myocardial damage that occurs following extensive RFA application $(5,6)$. This is the first study to report increased CSC count in limited myocardial damage that occurs following short- lasting local RF energy application due to AVRT and AVNRT.

Kim et al. have shown that peripheral blood CD34+ stem cell count increased significantly at 24 hours and 10 days after RFA in 46 patients with $A F(5)$. In the same study, they reported that SDF-1a levels were decreased after RFA and did not correlate with the change in CD34+ cell count (5). On the other hand, levels of matrix metalloproteinase- 9 (MMP-9) and growth regulated oncogene $\beta$ (GRO $\beta$ ) increased after RFA and correlated with the change in CD34+ cell count (5). Kim et al. have concluded that cardiac injury caused by RFA mobilizes CD34+ cells to the peripheral blood through a non-SDF-1a pathway associated with MMP-9 and GRO $\beta(5)$. In a further study by the same group, Shim et al. have revealed that the increase in post-RFA CD34+ cell count was more prominent in patients who underwent RF application for longer than 80 minutes(10). They have also shown that the change in CD34+ cell count was linearly correlated with the plasma Tn-I levels and associated with the procedural outcome following AF ablation (11).

Cangiano et al. have shown that peripheral blood CD34+ cell count was significantly increased at 7 and 10 days after the procedure in patients who underwent RFA for AF $(n=18)$ and atrial flutter $(n=11)(6)$. In this study, CD34+ cell count was found to be positively correlated with the vascular endothelial growth factor (VEGF) and SDF-1a levels.

In another study investigating the effects of RFA on systemic inflammatory changes and stem cell mobilization, Stein et al. have reported that the levels of inflammatory markers such as IL- 6, Tn- I and CRP were significantly increased following RF based pulmonary vein isolation (PVI) in 14 AF patients(11). In the same study, a significant decrease in SDF-1a levels was noted and CD34+CD133 + and CD117+ progenitor cell counts did not change significantly following RFA (11).

Up to now, studies evaluating stem cell mobilization and inflammatory changes following RFA have included patients that received long- lasting RF application (particularly AF patients) $(5,6,10-12)$. In our study, nearly all patients had an RFA duration of $<5$ minutes. Despite this fact, we detected a significant increase in peripheral blood CD34+ stem cell count following RFA. We demonstrated a significant increase in peripheral blood CD34+ cell count on the 7thday following the procedure. Our results are compatible with the results of Kim et al. and Cangiano et al. who 
reported an increase in the CD34+ cell count on the 7 th and 10thdays following $\operatorname{RFA}(5,6)$. Despite the fact that Shim et al. have shown a correlation between RFA duration and CD34+ cell count, we found that the CD34+ cell count was correlated with the RF power applied during the ablation. This inconsistency may be a result of the different RFA durations in these studies and points to diverse effects of procedural aspects on stem cell mobilization in different RFA protocols.

Although Cangiano et al. have demonstrated that SDF-1a level was correlated with the increase in CD34+ stem cells following RFA, other studies did not reveal such an association $(5,6,10)$. Kim et al. have shown that the increase in CD34+ cell count following RFA was associated with MMP- 9 and GRO $\beta$ levels (5). Similar to the results of Kim et al., our findings did not suggest a correlation between SDF-1a levels and the increase in CD34+ cell count following RFA. However, we did not investigate the relationship between CD34+ cell count and other stem cell stimulants such as VEGF, TNF- $\alpha$, MMP-9 or GRO $\beta$.

Previous studies investigating the inflammatory changes following RFA have reported increased levels of IL-6, Tn- I and CRP indicating an increased systemic inflammatory activity $(5,6,10-12)$. We have also found an increase in IL-6 and CRP levels following RFA, but these increases did not reach statistical significance possibly due to the small sample size of our study.

Major limitation of our study is the relatively small sample size. Furthermore, we did not investigate other stem cell subtypes and their functional roles, but only measured circulating CD34+ stem cell count. Further studies may provide these data.

\section{CONCLUSION}

The novelty of our study relies on the finding that even short- lasting ( $<5$ min) RFA in a limited area results in increased circulating CD34+ stem cell count. This finding may provide insight on determining the triggers of stem cell mobilization from the bone marrow and best strategy for cell- based clinical therapies.

Conflict of interest: Authors declare that there is no conflict of interest between the authors of the article.

Financial conflict of interest: Authors declare that they did not receive any financial support in this study.

Address correspondence to: Ahmet Lutfu Sertdemir, Department of Cardiology, Necmettin Erbakan University,
Konya, Turkey

Telephone: (0332) 2236000

e-mail:dralsertdemir@gmail.com

\section{REFERENCES}

1. Schomig K, Busch G, Steppich B, et al. Interleukin-8 is associated with circulating CD133+ progenitor cells in acute myocardial infarction. Eur Heart J 2006;27(9):1032-7.

2. Gill M, Dias S, Hattori $\mathrm{K}$, et al. Vascular trauma induces rapid but transient mobilization of VEGFR2(+)AC133(+) endothelial precursor cells. Circ Res 2001;88(2):167-74.

3. Kocher AA, Schuster MD, Szabolcs MJ, et al. Neovascularization of ischemic myocardium by human bone-marrow-derived angioblasts prevents cardiomyocyte apoptosis, reduces remodeling and improves cardiac function. Nat Med 2001;7(4):430-6.

4. Lapidot T, Petit I. Current understanding of stem cell mobilization: The roles of chemokines, proteolytic enzymes, adhesion molecules, cytokines, and stromal cells. Exp Hematol 2002;30(9):973-81.

5. Kim SK, Pak HN, Park JH, et al. Non-ischaemic titrated cardiac injury caused by radiofrequency catheter ablation of atrial fibrillation mobilizes CD34-positive mononuclear cells by non-stromal cell-derived factor-1alpha mechanism. Europace 2009;11(8):1024-31.

6. Cangiano E, Cavazza C, Campo G, et al. Different clinical models of CD34 + cells mobilization in patients with cardiovascular disease. J Thromb Thrombolysis 2011;32(1):1-8.

7. Goyal R, Zivin A, Souza J, et al. Comparison of the ages of tachycardia onset in patients with atrioventricular nodal reentrant tachycardia and accessory pathway-mediated tachycardia. Am Heart J 1996;132(4):765-7.

8. Calkins $\mathrm{H}$, Langberg $\mathrm{J}$, Sousa $\mathrm{J}$, et al. Radiofrequency catheter ablation of accessory atrioventricular connections in 250 patients. Abbreviated therapeutic approach to WolffParkinson-White syndrome. Circulation 1992;85(4):1337-46.

9. Jackman WM, Beckman KJ, McClelland JH, et al. Treatment of supraventricular tachycardia due to atrioventricular nodal reentry by radiofrequency catheter ablation of slow-pathway conduction. N Engl J Med 1992;327(5):313-8.

10. Shim J, Park JH, Kim JY, et al. Impaired mobilization of bone marrow derived CD34 positive mononuclear cells is related to the recurrence of atrial fibrillation after radiofrequency catheter ablation. Int J Cardiol 2013;162(3):179-83.

11. Stein A, Wessling G, Deisenhofer I, et al. Systemic inflammatory changes after pulmonary vein radiofrequency ablation do not alter stem cell mobilization. Europace 2008;10(4):444-9.

12. Manolis AS, Vassilikos V, Maounis $T$, et al. Detection of myocardial injury during radiofrequency catheter ablation by measuring serum cardiac troponin I levels: Procedural correlates. J Am Coll Cardiol 1999;34(4):1099-105. 